\title{
ILONA NARĘBSKA
}

Uniwersytet w Alicante

ilonarebska@gmail.com

\section{JADWIGA MAURIZIO - UZNANA, NIEZNANA, ZNAJOMA. TŁUMACZKA LEMA}

\section{Abstract}

\section{Jadwiga Maurizio - Acknowledged, Uknown, Familiar: Lem's Translator}

The list of translators who promoted Polish literature in Francoist Spain between 1939 and 1975 includes several dozen names. Many of them have remained anonymous. It is difficult to determine who they were and what kind of relationship they had with the Polish language, especially if we take into consideration that most of them were Spanish. Jadwiga Maurizio is one of the very few Polish women in that group. Spanish readers know her above all as Stanisław Lem's translator.

Despite the popularity of her work, she remains virtually unknown. She was undoubtedly a very exceptional yet modest woman. There is a lot to say about her translation work: the language she translated from, the strategies she used to deal with neologism and wordplay, the people who revised her translations.

This paper aims at bringing Jadwiga Maurizio out of the shadows to reveal her contribution to the translation of Polish literature. For this purpose, I will analyze the bibliography of books she translated in terms of the authors and editorial policy. I will try to figure out how she started to translate and what her cooperation with the publishing house looked like. I will also consider whether the quality of her translation had any influence on the popularity of Stanisław Lem in Spain. Finally, I will mention those facts from her private life that might have been related to her professional activity.

Key words: translation, Stanisław Lem, history of translation, Jadwiga Maurizio

Słowa kluczowe: przekład, Stanisław Lem, historia przekładu, Jadwiga Maurizio 
Jadwiga Maurizio jest znana w Hiszpanii przede wszystkim jako thumaczka Stanisława Lema, choć pierwszy przekład jej autorstwa to Szkice o Szekspirze Jana Kotta, wydane w 1969 roku, jeszcze w czasach dyktatury generała Franco. Była wówczas jedną z niewielu kobiet tłumaczących literaturę polską na hiszpański. To istotne, zwłaszcza że lista tłumaczy, którzy przyczynili się do promocji literatury polskiej w latach 1939-1975, liczy kilkadziesiąt nazwisk, a większość z nich to Hiszpanie ${ }^{1}$.

Kolejne tłumaczenia Jadwigi Maurizio ujrzały światło dzienne już w demokratycznej Hiszpanii. Wszystkie tytuły ukazały się nakładem barcelońskiego wydawnictwa Bruguera. Polska tłumaczka współpracowała z nim na przełomie lat 70. i 80. W ciągu sześciu lat, bo od 1977 do 1983 roku, barcelońska oficyna wydała w jej tłumaczeniu aż dziewięć tytułów Lema, wznawianych praktycznie do dziś.

W promocji Lema brały również udział inne wydawnictwa, współpracujące $\mathrm{z}$ innymi tłumaczami. Nie wszystkie dzieła polskiego pisarza zostały zresztą przetłumaczone bezpośrednio zjęzyka polskiego. Tymczasem bardzo dobrze odbierane przez hiszpańskich czytelników przekłady Polki w roku 1984 otrzymały nagrodę wydawnictwa Gigamesh. Hiszpańskie wersje futurystycznych wizji Lema powstały bez pomocy nowoczesnych technologii, które obecnie są podstawowym narzędziem każdego tłumacza. Niebywała jakość przekładów świadczy zatem o ogromnej erudycji, kreatywności oraz talencie lingwistycznym Maurizio.

Jako tłumaczka Lema Polka cieszy się uznaniem w hiszpańskim świecie fantastyki naukowej. Niemniej wciąż mamy do czynienia z postacią bliżej nieznaną. Dopiero dzięki osobom, które miały okazję spotkać ją i jej męża, Mariana Maurizia Abramowicza, dowiadujemy się więcej o życiu i kulisach twórczości translatorskiej polskiej tłumaczki Lema.

Magicznie brzmiące w języku polskim pojęcie „niewidzialności tłumacza” (translator's invisibility) zawdzięczamy Lawrence'owi Venutiemu (Venuti 1995). Amerykański przekładoznawca użył go, krytykując ekwiwalencję dynamiczną Eugene'a Nidy (Nida 1964), a tym samym strategię tłuma-

${ }^{1}$ Przeważnie to osoby zupełnie nieznane, niemal anonimowe. Nie ma o nich mowy w tradycyjnych, papierowych źródłach, a wyszukiwani w Internecie pojawiają się najczęściej w katalogach bibliotecznych. Sporo wiadomo o tłumaczących pisarzach czy poetach, czyli o tych, których działalność pisarska nie ograniczała się do przekładu. Ci tłumacze natomiast, którzy nie zaistnieli jako artyści, zwykle pozostają w cieniu przełożonych przez siebie dzieł. 
czeniową polegającą na nadmiernym udomowieniu tekstu. Zdaniem Venutiego thumacz staje się niewidzialny, gdy zbytnio dostosowuje oryginał do kultury docelowej. Może odzyskać widzialność poprzez zbliżenie odbiorcy do kultury oryginału.

Niezależnie od tego, za którą strategią opowie się tłumacz, opozycja „niewidzialność - widzialność” w ujęciu Venutiego odnosi się wyłącznie do tekstu. Nie ma tu mowy o thumaczu w sensie konkretnej osoby, wykonawcy zawodu. O ile w przypadku oryginału figura autora ma decydujące znaczenie, o tyle w przypadku tłumaczenia nazwisko schodzi na dalszy plan, zwłaszcza jeśli to nazwisko nosi kobieta. O tego rodzaju ,niewidzialności” pisze Fruela Fernández (Fernández 2012) w artykule zatytułowanym De la profesionalización a la invisibilidad: las mujeres en el sector de la traducción editorial [Od profesjonalizmu do niewidzialności: tłumaczki w branży wydawniczej].

Hiszpańska badaczka twierdzi, że większy udział kobiet w branży tłumaczeniowej w ostatnich dekadach nie wiąże się z większą ich widzialnością. Fernández sięga do badań socjologicznych, z których wynika, że tłumaczenie uważane tradycyjnie za zajęcie o mniejszej wadze i połączone z mniejszą odpowiedzialnością zwykło się uznawać za odpowiednie dla kobiet. Tymczasem postrzegana jako kreatywna i nadrzędna w stosunku do tłumaczenia twórczość literacka pozostawała domeną mężczyzn (Fernández 2012: 50). W konsekwencji „mało kreatywna” i „odtwórcza” praca nad przekładem okazała się dla kobiet swego rodzaju przepustką do świata literackiego (Fernández 2012: 51).

Nie oznacza to bynajmniej, że tłumaczenie stało się domeną kobiet. Fernández wskazuje na szereg czynników, które sprawiają, że tłumaczki są mniej widzialne od tłumaczy. Jak wynika $z$ badań przeprowadzonych przez autorkę, przekłady zrealizowane przez mężczyzn są częściej recenzowane niż przekłady zrealizowane przez kobiety (Fernández 2012: 52). Ponadto dzieła o większym kapitale symbolicznym, te „,bardziej formalne” i ,wzniosłe”, przypadają w udziale mężczyznom, podczas gdy gatunki o mniejszej wartości literackiej, ale przynoszące większy zysk, są przeznaczone dla kobiet (Fernández 2012: 54). Podobny podział jest widoczny również na płaszczyźnie językowej. Obecność mężczyzn jest zauważalna w przekładach z takich języków jak angielski, francuski, niemiecki, włoski, określanych w systemie międzynarodowym mianem , centralnych”. Tłumaczki zajmują niszę związaną z językami „,półperyferyjnymi” (rosyjski, chiński, arabski, japoński) i ,peryferyjnymi” (hebrajski, czeski, węgierski). Dodajmy, że 
przekłady z łaciny i greki, cieszące się uznaniem w kręgach literackich oraz uniwersyteckich, są również zdominowane przez tłumaczy płci męskiej (Fernández 2012: 57).

Zależność, jaką można zaobserwować w tym nieformalnym, choć powszechnie akceptowanym ,podziale obowiązków”, przypomina opozycję znaną z innych sfer zawodowych: profesor vs. nauczycielka, lekarz vs. pielęgniarka (Fernández 2012: 60). Na taki stan rzeczy ma wpływ samo podejście kobiet do pracy. Mężczyźni wysoko cenią sobie wynagrodzenie i uznanie społeczne, podczas gdy kobiety angażują się w dane zadanie już dla samej satysfakcji (Fernández 2012: 61).

Amalia Bosch Benítez w eseju poświęconym kobietom, pisarstwu i thumaczeniu rozwija ten wątek, rozważając kwestie natury „logistycznej". Tradycyjnie kobiety pracujące zawodowo zmuszone były do wyboru takiej pracy, która pozwalała im na wykonywanie obowiązków domowych. Obecnie, dzięki rozkwitowi nowych technologii i powszechnemu dostępowi do Internetu, kobiety mogą pogodzić działalność zawodową z opieką nad dziećmi i zajmowaniem się domem praktycznie bez wychodzenia $\mathrm{z}$ domu. To wyjaśniałoby, dlaczego tłumaczenie jest dla kobiet głównym zajęciem, podczas gdy mężczyźni zajmują się nim dodatkowo (Bosch Benítez 2000: 27).

Jak wynika z powyższych rozważań, na niewidzialność tłumaczek składa się wiele czynników. Dwa z nich wydają się najważniejsze: z jednej strony tłumaczenie jest uważane za zajęcie podrzędne w stosunku do pisarstwa, a z drugiej mężczyzna zajmuje w świecie przekładu pozycję bardziej uprzywilejowaną niż kobieta (Fernández 2012: 61-62).

W przypadku Jadwigi Maurizio należałoby dodać jeszcze jeden czynnik, także uwarunkowany kulturowo i społecznie, a mianowicie fakt, że była cudzoziemką i tłumaczyła na język obcy. Wszystkie jej tłumaczenia ukazały się w Hiszpanii. Niniejszy artykuł jest próbą wydobycia polskiej tłumaczki z niewidzialności.

Znana hiszpańskim czytelnikom Lema, zupełnie nieznana szerszej publiczności Jadwiga Maurizio nie była ani pisarką, ani poetką. Nie pozostawiła po sobie żadnych wspomnień. Źródeł mówiących o niej samej jest niewiele. $\mathrm{Ci}$, którzy mieli okazję ją poznać, potwierdzają, że była bardzo dyskretną kobietą i niechętnie o sobie opowiadała. Dlatego głównym celem niniejszego artykułu jest przybliżenie sylwetki Jadwigi Maurizio jako tłumaczki w kontekście przetłumaczonych przez nią książek. Mnie, z racji poszukiwań przekładoznawczych, najbardziej interesuje ten etap życia pani Jadwigi, który zaważył, jak sądzę, na jej popularności w hiszpańskim 
świecie literackim. Mam tu na myśli lata poświęcone tłumaczeniu polskiej literatury i czas publikacji pierwszych przekładów.

\section{Kraków, Zakopane, Barcelona}

Spoglądając w kalendarz, myślę o epoce, w jakiej przyszło żyć Jadwidze Maurizio. Badanie jej życia to podróż w czasie i w przestrzeni. Urodziła się jeszcze przed pierwszą wojną światową. Jej młodość przypadła na dwudziestolecie międzywojenne. Spędziła ją w Krakowie i Zakopanem. Do Barcelony zaś trafiła zaraz po wybuchu drugiej wojny światowej, a po zakończeniu hiszpańskiej wojny domowej. Poznała zatem przedwojenną Polskę oraz frankistowską, a później także demokratyczną, Hiszpanię.

Urodziła się w rodzinie inteligenckiej w 1910 roku jako Jadwiga Szenhak. Obcobrzmiące nazwisko zawdzięcza mężowi, Marianowi Maurizio Abramowiczowi ${ }^{2}$, którego poznała w czasie studiów. Ona studiowała wówczas romanistykę na Uniwersytecie Jagiellońskim, on był studentem krakowskiej Akademii Górniczo-Hutniczej. Pobrali się w 1935 roku, a cztery lata później, tuż po wybuchu wojny, wyjechali z Polski. Do 1942 roku mieszkali we Francji. Potem przenieśli się do Hiszpanii, gdzie spędzili resztę swojego życia. Na początku pobytu zatrzymali się u znajomych z Polski, Gabrieli i Stanisława Makowieckich. Obie panie znały się jeszcze ze studiów, wtedy jako Jadwiga Szenhak i „Ela” - jak mówili na nią przyjaciele - Rudnicka.

Wydaje się, że typowa dla polskiej kultury zmiana panieńskiego nazwiska jeszcze bardziej podkreśla kontrast między młodością Jadwigi spędzoną w przedwojennej Polsce a dorosłym życiem w powojennej Hiszpanii. „Moja młodość (...) to tańce, narty i wiosła. Moja młodość to Kraków i Zakopane" - wyznaje Jadwiga w wywiadzie, który przeprowadziła z nią niedługo przed śmiercią Lidia Chmielewska (Chmielewska 1997: 45). Do Zakopanego jeździła najpierw z rodzicami, a potem $\mathrm{z}$ narzeczonym.

Marian Maurizio Abramowicz, Polak ze szwajcarskimi korzeniami w rodowodzie, był wspaniałym kompanem i towarzyszem zabaw. Spokrewniony

2 Marian Maurizio Abramowicz (1905-1996), taternik, poeta, fotograf i inżynier rolnictwa.

3 Gabriela Makowiecka (1906-2002), polska hispanistka, popularyzatorka literatury polskiej w Hiszpanii, profesor Uniwersytetu Complutense w Madrycie. 
był z Malczewskimi, ale też z Marią Pawlikowską-Jasnorzewską i jej siostrą Magdaleną Samozwaniec, obie z domu Kossak. W willi Pawlikowskich „Pod Jedlami” Jadwiga zatrzymywała się wiele razy. Przez ten dom przewijali się - niekiedy dłużej się w nim zatrzymując - Jacek Malczewski, Karol Szymanowski, Kazimierz i Włodzimierz Tetmajer, Kasprowicz, Reymont i Żeromski, Sieroszewski, Korfanty i Dmowski, Modrzejewska, Stanisław Grabski, Karol Stryjeński i Witkacy, arcybiskup Stablewski i Leon Wyczółkowski, i jeszcze wielu, wielu sławnych ludzi (Chmielewska 1997: 45-46).

Po ślubie młodzi Mauriziowie zamieszkali na ulicy Garncarskiej w Krakowie (Chmielewska 1997: 46). Wtedy Jadwiga ,dużo czytała i tłumaczyła z języka francuskiego" (Chmielewska 1997: 46). Korzystała z dobrodziejstw kulturalnych Krakowa lat 30., często bywała w teatrze. Jej ulubionym aktorem był Juliusz Osterwa, a aktorką - Zofia Jaroszewska (Chmielewska 1997: 46).

Początki nowego życia w obcym kraju z pewnością nie były łatwe. Z Francji do Hiszpanii ściągnęli Jadwigę i Mariana Makowieccy, którzy mieli niedużą posiadłość niedaleko Barcelony. Jak twierdzi Grzegorz Bąk, po zakończeniu wojny domowej ,panował prawdziwy głód, brakowało podstawowych artykułów spożywczych”, a kataloński dom Makowieckich został „zrujnowany i splądrowany” (Bąk 2008: 49). „Obie pary [Makowieccy i Mauriziowie] wzajemnie się wspierały, wspólnie pokonując trudności, jakie napotykali mieszkańcy Hiszpanii lat czterdziestych" (Bąk 2008: 49).

Kiedy „Dzik”, bo takim przydomkiem obdarzyli Mariana znajomi, dostał pracę w szwajcarskiej firmie Ciba Geigi, Mauriziowie mogli się uniezależnić. Wprawdzie od 1944 do 1947 roku kilkakrotnie zmieniali mieszkania, ale, jak zapewnia Jadwiga, jej „wszędzie było wygodnie i wesoło” (Chmielewska 1997: 46). W roku 1948 mogli zamieszkać w Barcelonie na stałe.

\section{Polska literatura w Hiszpanii po 1939 roku}

Pojawienie się Jadwigi Maurizio na hiszpańskiej scenie literackiej wiąże się głównie z przekładami twórczości Stanisława Lema, a także z obecnością teatru polskiego w Hiszpanii, co z kolei jest konsekwencją przemian w polityce wydawniczej po zakończeniu hiszpańskiej wojny domowej. Przyjrzyjmy się zatem, jak kształtowała się w tym kraju recepcja literatury polskiej po 1939 roku (Narębska 2015), by zobaczyć, w jakim momencie przypadło Polce w udziale tłumaczyć swoich rodaków na język obcy. 
Możemy śmiało mówić o trzech tendencjach w podejściu hiszpańskich wydawców do literatury z Polski: ekonomicznej, politycznej i artystycznej. Warto też zauważyć, że znakomita większość polskich utworów ukazała się w Madrycie i w Barcelonie (Narębska 2015).

Pierwsze lata po wojnie - lata 40. - to przede wszystkim wznowione wydania przedwojennych klasyków. Wydawcy sięgają po stare, sprawdzone bestsellery, by stanąć znowu na nogi. Do takich ,pewniaków” polskiego pochodzenia należał Henryk Sienkiewicz (najpopularniejszą jego powieścią było Quo vadis) oraz drugi polski noblista, Władysław Stanisław Reymont i jego Chłopi, jak również powieści przygodowe Antoniego Ossendowskiego. W latach 50. pojawiło się sporo nowych wydawnictw, które chętnie sięgały po literaturę współczesną. Czynnik polityczny był tu szczególnie istotny, bo literatura polska oznaczała głównie literaturę emigracyjną, krytykującą znienawidzony przez generała Franco komunizm. Hiszpański czytelnik mógł wtedy poznać twórczość Marka Hłaski, Leopolda Tyrmanda czy Sergiusza Piaseckiego. Do wyjątków z literatury tworzonej w Polsce należał chrześcijański pisarz Jan Dobraczyński. Połowa lat 60. to niejako zapowiedź nowego porządku politycznego, powiew demokracji. Lewicowe, głównie katalońskie wydawnictwa stały się prekursorami nowej strategii edytorskiej. To dzięki nim na księgarskie półki trafiała polska literatura awangardowa z okresu międzywojnia: Witold Gombrowicz, Stanisław Ignacy Witkiewicz, Bruno Schulz. Ważne miejsce w ostatnich latach dyktatury zajmowały także przekłady polskich sztuk teatralnych, m.in. Tadeusza Różewicza i Sławomira Mrożka. To właśnie wtedy rozpoczęła się działalność translatorska Jadwigi Maurizio, początkowo za sprawą wzmożonego zainteresowania teatrem polskim, a później - fantastyką naukową w wydaniu Stanisława Lema.

\section{Szkice o Szekspirze Jana Kotta}

W 1969 roku, osiem lat po ukazaniu się polskiego oryginału, barcelońskie wydawnictwo Seix Barral wydało Apuntes de Shakespeare, czyli Szkice o Szekspirze autorstwa Jana Kotta. Rozprawa polskiego krytyka była $\mathrm{w}$ tamtym czasie jedynym wydanym w Hiszpanii polskim dziełem teoretycznym dotyczącym teatru. Wszystkie inne publikacje książkowe z Polski to sztuki teatralne. Należy domniemywać, że decydujący wpływ na publikację Szkiców w Hiszpanii miała uniwersalna tematyka dzieła. Przekładu 
Szkiców o Szekspirze dokonała Jadwiga Maurizio, debiutując tym samym jako tłumaczka literatury polskiej na hiszpański ${ }^{4}$.

Warto dodać, że do niedawna było to nie tylko pierwsze, ale i jedyne hiszpańskie wydanie książki Kotta. W 2007 roku w wydawnictwie Alba ukazała się poszerzona wersja: Shakespeare, nuestro contemporaneo (Szekspir współczesny) w tłumaczeniu Katarzyny Olszewskiej Sonnenberg i Sergia Trigána.

\section{Wydania Lema}

Współpraca polskiej tłumaczki z wydawnictwem Seix Barral w pewnym sensie była zwiastunem jej późniejszej kariery translatorskiej. To właśnie Seix Barral, od 1970 roku funkcjonujące pod nazwą Barral Editores, zapoczątkowało bowiem obecność Stanisława Lema w Hiszpanii. W 1975 roku ukazał się jego nakładem Kongres futurologiczny w tłumaczeniu Melitona Bustamantego, który dwa lata później przełożył Bajki robotów dla wydawnictwa Guardarrama. Choć Bustamante tłumaczył bezpośrednio z polskiego, a książki Lema cieszyły się popularnością, obie firmy wydawnicze na tych tytułach zaprzestały promocji polskiego pisarza.

Nie znaczy to, że o Lemie całkiem zapomniano. Przeciwnie, w ślady Barral Editores i Guardarramy poszło jedno z najważniejszych barcelońskich wydawnictw literatury popularnej, a mianowicie Bruguera. To tu, już w demokratycznej Hiszpanii, ujrzały światło dzienne kolejne tłumaczenia Jadwigi Maurizio. Na przełomie lat siedemdziesiątych i osiemdziesiątych Bruguera opublikowała aż osiem nowych tytułów Lema, nie licząc nowego thumaczenia Bajek robotów. Po wydanych w 1977 roku Śledztwie i Pamiętniku znalezionym w wannie przyszła kolej na Powrót z gwiazd, Dzienniki gwiazdowe, Cyberiadę, Doskonała próżnię, Katar oraz Wielkość urojona. Wszystkie te pozycje ukazały się w tłumaczeniu Jadwigi Maurizio, choć przy niektórych tytułach widnieje również nazwisko Pilar Giralt Goriny. Bruguera była jedynym wydawnictwem, które tak konsekwentnie stawiało na promocję Lema, niedługo bowiem po pierwszym wydaniu większość $\mathrm{z}$ wymienionych tytułów opublikowano tu ponownie.

${ }^{4}$ Dzieło Kotta było pierwszym i ostatnim tytułem przetłumaczonym przez Polkę dla tego wydawnictwa. 
Można by sądzić, że barcelońska oficyna miała wystarczająco ugruntowaną pozycję na rynku, by lata współpracy z polską tłumaczką zwieńczyć wydaniem Solaris. Tymczasem najpopularniejszą powieść Lema wydał specjalizujący się w literaturze science fiction Minotaur. Dlaczego tak się stało? Czy Bruguera świadomie i zupełnie dobrowolnie zrezygnowała z Solaris? Być może przyczyną było to, że barcelońskie wydawnictwo było bardziej ukierunkowane na literaturę popularną, a Minotaur specjalizował się w science fiction. Choć trudno to teraz ustalić z całą pewnością, należy się domyślać, że istotną rolę odegrały tu względy komercyjne. Chodziło bowiem o powieść, która kilka lat wcześniej doczekała się dwóch ekranizacji ${ }^{5}$, nie mówiąc o licznych tłumaczeniach na języki obce.

Przetłumaczone z angielskiego Solaris stanowi swego rodzaju punkt zwrotny w historii wydawniczej Lema w Hiszpanii: z jednej strony przerywa monopol Bruguery, a z drugiej, choć zabrzmi to paradoksalnie, zwiastuje koniec lemowskiego boomu. Chociaż na przełomie lat 80. i 90. pojawia się kilka nowych przekładów, to większość publikacji stanowią wznowienia. Firmą wydawniczą, która w pewnym sensie zajmuje miejsce Bruguery, jeśli chodzi o Lema, jest Alianza.

\section{Przekłady Jadwigi Maurizio}

W latach 1977-1983 Bruguera opublikowała dziewięć tytułów Lema przetłumaczonych przez Polkę. Możemy mówić o stałej i intensywnej współpracy tłumaczki z wydawnictwem: w ciągu zaledwie sześciu lat ukazało w sumie osiem nowych pozycji oraz Bajki robotów w nowym przekładzie.

Skromny, ale cenny ślad współpracy z Bruguerą zawierają listy, które Marian Maurizio pisał do Henryka Woźniakowskiego, publicysty, wydawcy i tłumacza, związanego wówczas i obecnie ze Społecznym Instytutem Wydawniczym „Znak”. 27 lutego 1977 roku „Dzik” pisze: „U nas nic nowego; Jadwiga tłumaczy, daje lekcje”. Na dole widnieje odręczny dopisek Jadwigi: „Pierwszy Lem już ukończony: Śledztwo. Następny: Rękopis znaleziony $w$ wannie. Dwa następne - jeszcze nie wiem” (Maurizio 1977: 27.02).

Kolejny list, z 4 lipca 1977, rozwiewa wątpliwości. Mąż tłumaczki zdaje przyjacielowi relację $\mathrm{z}$ atmosfery panującej w domu i opowiada o wrażeniach z lektury Lema:

5 1970, ZSRR, reż. Nikołaj Nirenburg; 1972, ZSRR, reż. Andriej Tarkowski. 
Jadwiga furt tłumaczy Lema; czasem ukradkiem uda mi się co dołapać, żeby poczytać i zaiste to fajny pisarz! fantazje ma nie przeciętną! pomysły świetne, $\mathrm{z}$ tem że wiele $\mathrm{z}$ nich aż za przejrzyście wyglądają! a sama narracja jest bezpośrednia i lekka i trzyma w napięciu! fajny pisarz! podoba mi się. Chciałbym ja w mojej gwarze tak się lekko obracać, jak on w swojej ,,science-fiction!” Dzięki za książkę o nim, którąś przysłał, bardzo interesujący dodatek do poznania autora i dobrze ujęta (Maurizio 1977: 4.07).

Wszystko wskazuje na to, że Jadwiga pracuje wtedy nad Powrotem z gwiazd i Dziennikami gwiazdowymi, które ukażą się rok później, w 1978 roku.

We wszystkich wydaniach Powrotu do gwiazd obok nazwiska Jadwigi Maurizio widnieje również nazwisko Piral Giralt Goriny. W przypadku Kataru sprawa nie jest do końca jasna, nazwiska obu pań pojawiają się bowiem dopiero $\mathrm{w}$ trzecim wydaniu, z roku 1983. W dwóch poprzednich (z 1978 i z 1979 roku) podano tylko nazwisko Giralt Goriny. Jest raczej mało prawdopodobne, żeby Maurizio ingerowała w tłumaczenie Giralt po sześciu latach. Może więc chodzi po prostu o przeoczenie nazwiska. Tego typu zaniedbania w minionych dekadach (niepoprawnie zapisane nazwisko autora, a nawet brak nazwiska tłumacza) zdarzały się dość często.

List Mariana Maurizia z 26 marca 1984 roku tym razem nie rozstrzyga sprawy: „U nas nic się nie zmieniło w trybie życia. Tyle, że Jadwiga teraz ma mniej tłomaczeń, widać rynek już się nasycił Lemem. Przetłomaczyła osiem jego książek, to już cosi jest" (Maurizio 1984: 26.03). Gdyby nie fakt, że w trzecim wydaniu Kataru z 1983 roku obok Giralt Goriny pojawia się również nazwisko Maurizio, wszystko by się zgadzało.

W 1984 Maurizio otrzymuje nagrodę wydawnictwa Gigamesh za przekłady twórczości Lema. Choć wznowienia jej tłumaczeń będą się ukazywać przez przynajmniej kolejne kilkanaście lat, to na rynek wydawniczy nie wejdzie już żaden nowy przekład jej autorstwa. Nie dlatego jednak, że jak zauważył Marian Maurizio - ,rynek nasycił się Lemem”, bo zaledwie rok później pojawi się pierwsze, wspomniane wcześniej wydanie Solaris w przekładzie Matilde Horne, Argentynki, znanej przede wszystkim z thumaczeń trylogii Tolkiena.

Zachodzi tu zatem sytuacja analogiczna jak w przypadku Bruguery i Minotaura. Bruguera po wydaniu Wielkości urojonej w 1983 roku z niewiadomych powodów nie sięgnęła po Solaris, mimo że miała ku temu dość powodów. Powieść Lema była gwarantem prestiżu i sukcesu wydawniczego, a wydawnictwo mogło ponownie zaoferować czytelnikom przekład bezpośrednio z polskiego. Podobnie Jadwiga Maurizio, nagrodzona w 1984 roku 
przez wydawnictwo Gigamesh, spełniała wszystkie warunki, by kontynuować karierę translatorską. Miała doświadczenie w thumaczeniu Lema, a jej dorobek zyskał aprobatę i uznanie. Mogła przetłumaczyć Solaris dla Minotaura, ale nowy wydawca najwyraźniej wolał współpracę z Matilde Horne, która przetłumaczyła już dla niego Władce pierścieni.

\section{Gigamesh, uznanie wydawców, pochwała czytelników}

Nagroda wydawnictwa Gigamesh świadczy o ogromnym uznaniu, jakim cieszyły się przekłady Jadwigi Maurizio w świecie wydawniczym. Wyróżnienie stanowi podsumowanie jej kariery translatorskiej i trudno stwierdzić, dlaczego ani Bruguera, ani inne oficyny nie zaprosiły polskiej tłumaczki do współpracy nad przekładami z polskiego. Wprawdzie nie wiemy, jak sama Jadwiga Maurizio zareagowała na tę nagrodę, ale z listu jej męża do Henryka Woźniakowskiego wynika, że było to ważne wydarzenie, bo, jak pisze „Dzik”, „Zrobili jej tu wielkie homenage ${ }^{6}$ w Wydawnictwie, przyjęcie, osobistości, dyplom dla najlepszej tłomaczki” (Maurizio 1984: 27.10).

O uznaniu wydawców świadczą również najnowsze reedycje. Zarówno Dzienniki gwiazdowe z 2013 roku, jak i Powrót z gwiazd oraz Cyberiada z 2015 roku ukazały się w przekładzie Jadwigi Maurizio. Spośród książek przetłumaczonych przez Polkę tylko jedna doczekała się nowego przekładu. Mowa o Śledztwie wydanym przez oficynę Impedimenta w roku 2011 w thumaczeniu Joanny Orzechowskiej. Warto przy tym zwrócić uwagę, że wznowiona przez tego samego wydawcę rok wcześniej Wielkość urojona nie ukazała się w nowej wersji, lecz w przekładzie Maurizio. Podobnie rzecz się ma z Próżnią doskonatą opublikowaną przez Impedimentę w roku 2008 w niezmienionej wersji.

Jeśli Bruguera była na większą skalę prekursorką w publikowaniu Lema na przełomie lat 70. i 80., a Alianza podtrzymała tę tradycję w latach 90. i na początku XX wieku, to Impedimenta jest ich współczesną spadkobierczynią. Mamy do czynienia z wydawnictwem, którego działalność nie ogranicza się wyłącznie do wznawiania. Impedimenta odkrywa Lema na nowo, publikując z rozmysłem i rozwagą, co w praktyce oznacza między

\footnotetext{
${ }^{6}$ Chodzi o hiszpańskie słowo homenaje [omenahe], oznaczające uroczystość zorganizowaną na czyjąś cześć.
} 


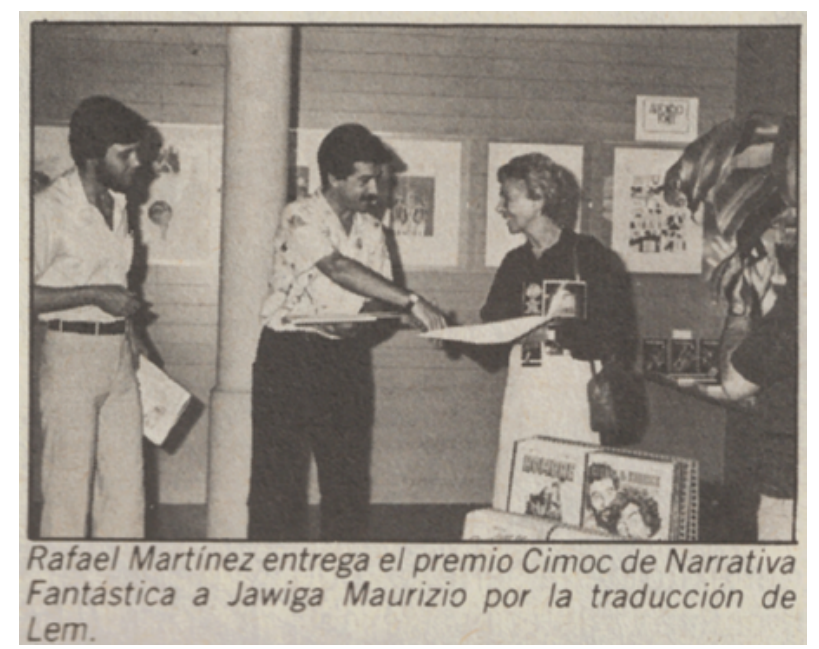

Fotografia 1. Rafael Martínez wręcza Jadwidze Maurizio nagrodę Cimoc de Narrativa Fantástica za przekład Lema. Po lewej Alejo Cuervo, dyrektor wydawnictwa Gigamesh. Źródło: „Cimoc” 42 (1984), Norma Editorial.

innymi dbałość o jakość przekładu. To tu w roku 2011 ukazuje się pierwsze Solaris Lema przełożone bezpośrednio z polskiego. Przy tej okazji powraca nazwisko Jadwigi Maurizio. Jeden z recenzentów nowej wersji wspomina, że Solaris zawsze wydawało mu się mniej klarowne niż pozostałe dzieła Lema właśnie z powodu podwójnego tłumaczenia. „W Bruguerze przekłady zawsze były realizowane bezpośrednio z polskiego przez Jadwigę Maurizio i zawsze wydawały mi się wspaniałe. Jakże niezrozumiałe mogłyby być Śledztwo, Katar czy inne powieści o takiej złożoności” (Des Frankenstein 2011, przeł. I.N.).

Fenomen Jadwigi Maurizio polega również na tym, jak dużo dobrego mówią o jej tłumaczeniach hiszpańskojęzyczni czytelnicy. Ich zdaniem Polka fantastycznie sobie radzi ze złożoną leksyką Lema, czego przykładem są Bajki robotów, pełne neologizmów i gier słownych, oraz ze skomplikowaną treścią, jak to się dzieje w Doskonałej próżni. Należy to uznać za nie lada komplement, wziąwszy pod uwagę, że czytelnicy Lema chętnie komentują jakość tłumaczeń. Od kilku lat podawali w wątpliwość jakość i wiarygodność Solaris przełożonego na hiszpański z angielskiego (Illaregui 2007). Wreszcie doczekali się nowej wersji. Nie dowiemy się jednak, jak wypadłoby Solaris w wykonaniu Jadwigi Maurizio. 
Przyczyną publikowania nowych wersji jest nie tylko niewystarczająca jakość starszych przekładów, lecz także specyficzne wymagania czytelników. Nie mam tu na myśli kaprysów czytelniczych, lecz kwestię odmiany języka hiszpańskiego. Z recenzji Juana de Marsilio zamieszczonej w argentyńskim wydaniu dziennika El País dowiadujemy się, że:

Lema czytano w [argentyńskim - I.N.] Río de la Plata na początku lat 80. dzięki wydaniom Bruguery, a potem prestiżowego Minotaura, nie tylko w kręgach miłośników science fiction, lecz także wśród „bardziej wymagających” czytelników. Później jego książki zaczęły się ukazywać w wydawnictwie Alianza Editorial (Marsilio 2016, przeł. I.N.).

Oznacza to, że tłumaczenia Jadwigi Maurizio czytali nie tylko Hiszpanie.

W 2015 roku argentyńskie wydawnictwo Interzona zdecydowało się wydać nowy przekład Pamiętników znalezionych $w$ wannie właśnie z powodu odmian językowych. Dla tłumaczki z Ameryki Południowej było to podwójne wyzwanie, bo, jak się okazuje, jej ,rywalem” był nie tylko kreatywny Lem, lecz także wybitna Maurizio.

Przekład Barbary Gill musiał się zmierzyć ze znakomitymi tłumaczeniami Jadwigi Maurizio, które wprawdzie w neutralnej odmianie języka kastylijskiego z Półwyspu [Iberyjskiego] skutecznie oddawały absurd, błyskotliwą ironię gier słownych i dyskursywny patetyzm niektórych postaci, ale czytelnikowi stąd brzmiały obco - brakowało w nich lokalnego żargonu. Nowy przekład trafia w sedno, zwłaszcza jeśli chodzi o ten ostatni aspekt: o wyrażenia idiomatyczne typowe dla mowy mieszkańców Rio de la Plata (Marsilio 2016, przeł. I.N.).

\section{Warsztat tłumaczki}

Ze wspomnień hiszpańskiej chrześnicy Maurizio, Ann Bofill Shanly, z którą kilka lat temu udało mi się nawiązać kontakt, dowiadujemy się nieco więcej o tym, jak wyglądały warsztat tłumaczki oraz jej zaplecze intelektualne. Jadwiga Maurizio korzystała z maszyny do pisania stojącej na biurku przy łóżku, tuż obok telefonu. Do tłumaczeń używała kalki, miała bardzo zgrabne, charakterystyczne pismo - wspomina Ann. Hiszpańskie wersje futurystycznych wizji Lema powstały bez pomocy nowoczesnych technologii, które obecnie są podstawowym narzędziem każdego tłumacza. Niebywała jakość przekładów świadczy zatem o ogromnej erudycji, kreatywności oraz talencie językowym Jadwigi Maurizio. 
Niewykluczone, że Jadwiga odziedziczyła zamiłowanie do literatury po matce polonistce. Od Ann Bofill wiemy też, że chętnie sięgała po literaturę francuską (Colette, Antoine'a de Saint-Exupéry’ego, Françoise Sagan, André Maurois...) oraz niektóre dzieła Lwa Tołstoja. Z poezji szczególnie upodobała sobie skamandrytów: Staffa, Gałczyńskiego, Tuwima i Lechonia. Czytywała również wiersze Federica Garcíi Lorki i Rafaela Albertiego. Ann Bofill dodaje też, że Jadwidze bliska była atmosfera kulturalna Europy z przełomu XIX i XX wieku: Balety rosyjskie Diagilewa, życie paryskiej bohemy (takie postacie jak Jean Cocteau, Coco Chanel, Misia Godebska), działalność artystów związanych z grupą Bloomsbury oraz innych intelektualistów tamtej epoki. Uwielbiała teatr. ,Teatr był najważniejszy. Chodzenie na premiery stało się jakby moralnym obowiązkiem krakowskiej inteligencji”. Na pytanie o ulubionego malarza bez wahania odpowiadała: Wyspiański (Chmielewska 1997:46).

Jak zapewnia Ann Bofill, jej chrzestna była pełna podziwu dla twórczości thumaczonych przez siebie pisarzy: wybitnego krytyka teatralnego Jana Kotta oraz autora fantastyki naukowej Stanisława Lema. To temu drugiemu polska tłumaczka zawdzięcza swoją popularność w hiszpańskim świecie literackim. A fakt, że Lem był i jest tak chętnie czytany w Hiszpanii, to w dużej części zasługa talentu translatorskiego Polki.

Przypomnijmy, że Jadwiga Maurizio tłumaczyła z języka ojczystego na język obcy. Wiadomo, że przy Powrocie z gwiazd i przy Katarze współpracowała z Hiszpanką Pilar Giralt, lecz w pozostałych książkach nie pojawia się nazwisko innego tłumacza. Trudno powiedzieć, czy Maurizio liczyła na jakąś nieformalną pomoc lingwistyczną i czy każdy przekład przechodził wnikliwą korektę w wydawnictwie. W każdym razie należy przyjąć, że w latach 70. Jadwiga Maurizio była już doświadczoną tłumaczką i mieszkała w Barcelonie dość długo, by posługiwać się swobodnie językiem hiszpańskim. Ann Bofill zapewnia, że zarówno Jadwiga, jak i Marian mówili płynnie po hiszpańsku. Jako absolwentka filologii romańskiej Jadwiga Maurizio znała też bardzo dobrze francuski i, jak podaje Lidia Chmielewska, w latach 30. zajmowała się tłumaczeniem z tego języka (Chmielewska 1997: 46).

Ann Bofill wspomina $\mathrm{z}$ kolei, że w latach 70. Jadwiga wykonywała thumaczenia ustne związane z przeszczepami nerek, najpewniej na zlecenie polskiego konsulatu. Dodaje przy tym, że Jadwiga Maurizio była bardzo dyskretna, nie miała zwyczaju mówić o sobie ani o tym, co i jak tłumaczy. Możemy zatem domniemywać, że takich mniej lub bardziej sporadycznych 
tłumaczeń ustnych oraz pisemnych było więcej, co potwierdzają fragmenty listów jej męża: „U nas nic nowego; Jadwiga tłumaczy, daje lekcje” (Maurizio 1977: 27.02), „Jadwiga ma się dobrze, na razie nie tłomaczy Lema, jakieś tam drobiazgi" (Maurizio 1984: 27.10).

Piotr Worytkiewicz, kustosz Muzeum Etnograficznego w Krakowie, z którym nawiązałam kontakt dzięki Ann Bofill, a który w latach 90. odwiedzał kilkakrotnie dom państwa Maurizio w Barcelonie, wspomina, że pani Jadwiga bardzo lubiła rozmawiać na tematy lekkie i okraszone humorem, a jej pogodny nastrój udzielał się rozmówcom. Czasem po prostu zagadywała o miniony dzień, o plany na następny. Niekiedy ogarniała ją melancholia i wtedy rozmowy dotyczyły poważnych tematów. Również Bożena Zaboklicka, profesor Uniwersytetu Barcelońskiego, która na początku lat 80., podobnie jak Jadwiga, pracowała w Bruguerze, zapamiętała tłumaczkę Lema jako uroczą panią, typową polską inteligentkę lubiącą otaczać się ludźmi, z którymi można było ciekawie porozmawiać. Lidia Chmielewska w swoim artykule zwraca uwagę na takt i erudycję osiemdziesięcioparoletniej wówczas tłumaczki. „Świeci jak gwiazda i wciąż do siebie przyciąga. Bo to niezwykła osoba, nienudna" - puentuje spotkanie dziennikarka (Chmielewska 1997: 46).

„Świeci jak gwiazda i wciąż do siebie przyciąga”. Te słowa wybrzmiewają na nowo kilkanaście lat po śmierci Jadwigi Maurizio (1910-2000). W Hiszpanii nazwisko tłumaczki Lema powraca wraz z publikacjami nowych przekładów jako wzorzec i punkt odniesienia. W Polsce dopiero poznajemy żonę Mariana Maurizia Abramowicza i uznaną tłumaczkę Lema.

7 W 2015 roku dzięki inicjatywie krakowskiego Muzeum Etnograficznego im. Seweryna Udzieli i Muzeum Tatrzańskiego w Zakopanem odbyła się pierwsza konferencja popularnonaukowa poświęcona Marianowi i Jadwidze Maurizio, towarzysząca wystawie „Ku Tatrom się zwrócę... Z Hiszpanii do Zakopanego. Życie i dzieło Mariana i Jadwigi Maurizio”). 
Hiszpańskie przekłady Jadwigi Maurizio

na podstawie internetowego katalogu Hiszpańskiej Biblioteki Narodowej (BNE)

Szkice o Szekspirze, Jan Kott

Apuntes sobre Shakespeare

Seix Barral, 1969

Śledztwo, Stanisław Lem

La Investigación ${ }^{8}$

Bruguera, 1977, 1979, 1980, 1986

Suma de Letras, 2000

Pamiętnik znaleziony w wannie, Stanisław Lem

Memorias encontradas en una bañera

Bruguera, 1977, 1979, 1983,

Edhasa, 1987

Powrót z gwiazd, Stanisław Lem

Retorno de las estrellas ${ }^{9}$

Bruguera, 1978, 1980, 1983, 1986

Alianza, 1993, 2005, 2015

\section{Dzienniki gwiazdowe, Stanisław Lem}

Diarios de las estrellas

Bruguera, 1978, 1979, 1983, 1985

Edhasa, 1988, 2003

Suma de Letras, 2000

Alianza, 2005, 2013

Cyberiada, Stanisław Lem

Ciberíada

Bruguera, 1979, 1980, 1983, 1986

Alianza, 1988, 2005, 2015

Círculo de Lectores, 2004

Doskonala próżnia, Stanisław Lem

Vacío perfecto

Bruguera, 1981

Ediciones B, 1988

Impedimenta, 2008

${ }^{8}$ W 2011 roku Impedimenta wznowiła publikację Śledztwa w nowym tłumaczeniu Joanny Orzechowskiej.

9 Przekład dokonany przez Jadwigę Maurizio i Pilar Giralt Gorinę. 


\section{Bajki robotów, Stanisław Lem \\ Fábulas de robots ${ }^{10}$}

Bruguera, 1981

\section{Katar, Stanisław Lem}

La fiebre de heno ${ }^{11}$

Bruguera, (1978, 1979), 1983

Suma de Letras, 2002

\section{Wielkość urojona, Stanisław Lem}

Un valor imaginario

Bruguera, 1983

\section{Magnitud imaginaria}

Impedimenta, 2010

\section{Bibliografia}

Bąk G. 2008. Wybitne postacie madryckiej Polonii: Juliusz Babecki, Karolina Babecka, Józef Łobodowski, Kazimierz Tylko, Gabriela Makowiecka, w: I. Barlińska, M. Raczkiewicz, M. Stanek (red.), Polonica Matritensis, Kraków: Homo Dei, t. I, s. 25-53.

Bosch Benítez A. 2000. Algunos apuntes sobre mujer, escritora y traducción, w: A.S. Ramírez Jaime (red.), Mujer e identidad, distintas voces: ensayos de literatura y traducción, Las Palmas de Gran Canaria: Chandlon Inn Press, s. 15-28.

Chmielewska L. 1997. Sardany już nie zatańczę, „Sukces”, grudzień.

Des Frenkenstein. 2011. Solaris de Stanisław Lem, 29 czerwca, http://www.literaturaprospectiva.com/?p=7988 (dostęp: 29.02.2016).

Fernández F. 2012. De la profesionalización a la invisibilidad: las mujeres en el sector de la traducción editorial, „Trans” 16, s. 49-64.

Illaregui N. 2007. ¿Pero qué Solaris hemos leído?, 6 lutego, http://aburreovejas. com/2007/02/06/\%C2\%BFpero-que-solaris-hemos-leido/ (dostęp: 29.02.2016).

Maurizio M. 1977. List Mariana Maurizia do Henryka Woźniakowskiego, Barcelona, 27 lutego.

1977. List Mariana Maurizia do Henryka Woźniakowskiego, Barcelona, 4 lipca. 1984. List Mariana Maurizia do Henryka Woźniakowskiego, Barcelona, 26 marca. 1984. List Mariana Maurizia do Henryka Woźniakowskiego, Barcelona, 27 października.

10 Jest to drugie wydanie, a zarazem drugi przekład Bajek robotów. Tłumaczenie opublikowane w 1977 roku przez wydawnictwo Guardarrama nie zostało wznowione.

${ }_{11}$ Według informacji z wydania z 1983 roku Katar, podobnie jak Powrót z gwiazd, został przetłumaczony przez Jadwigę Maurizio i Pilar Giralt Gorinę. W pierwszych dwóch wydaniach, z 1978 i 1979 roku, widnieje tylko nazwisko Pilar Giralt Goriny. 
Marsilio J. de 2016. Arqueología en la bañera, „El País”(Uruguay), 5 lutego, http://www. elpais.com.uy/cultural/arqueologia-banera-stanislaw-lem.html (dostęp: 21.12.2016).

Narębska I. 2011. Lem w Hiszpanii. Wydawnictwa, thumacze, czytelnicy, w: E. Skibińska, J. Rzeszotnik (red.), Lem i tlumacze, Kraków: Księgarnia Akademicka, s. 225-241. 2015. Literatura polaca en España (1939-1975): autores, editores, traductores, Wrocław: Wydawnictwo Wyższej Szkoły Filologicznej we Wrocławiu.

Nida E. 1964. Towards a Science of Translation, Nowy Jork: Prentice Hall.

Sawicki P. 2013. „Hiszpańskie lata” pani Gabrieli, w: P. Sawicki, Polska-Hiszpania, Hiszpania - Polska. Porzerzanie horyzontów, Wrocław: Wydawnictwo Wyższej Szkoły Filologicznej we Wrocławiu, s. 237-240.

Urbanek D. 2006. Egzystencjalne problemy thumaczenia a ideologizacja postawy thu$m a c z a$, w: P. Fast, P. Janikowski (red.), Dialog czy nieporozumienie (z zagadnień krytyki przekładu), Katowice-Warszawa-Częstochowa: Wydawnictwo Wyższej Szkoły Lingwistycznej, s. 21-36.

Venuti L. 1995. The Translator's Invisibility. A History of Translation, London-New York: Routledge.

Katalog Hiszpańskiej Biblioteki Narodowej, http://www.bne.es (dostęp: 29.02.2016). Baza danych ksiązek opublikowanych w Hiszpanii, http://www.mecd.gob.es/cultura-mecd/areas-cultura/libro/bases-de-datos-del-isbn/base-de-datos-de-libros.html (dostęp: 29.02.2016).

Serdeczne podziękowania dla pani Ann Bofill Shanly, pana Piotra Worotkiewicza, pana Jacka Kukuczki, pana Henryka Woźniakowskiego, pani Bożeny Zaboklickiej oraz Borhy Vargasa za udzielone informacje i udostępnione materiały. 